\title{
TANTANGAN DAN STRATEGI PENDIDIKAN ISLAM DALAM MEWUJUDKAN SISWA DAN SEKOLAH BERKUALITAS
}

\author{
Jenuri $^{1}$
}

\begin{abstract}
ABSTRAK
Pendidikan Agama Islam adalah ruh dalam pembentukan siswa berkualitas di sekolah. Perlu strategi yang tepat untuk mewujudkannya. Perubahan yang terjadi di Indonesia berdampak menimbulkan krisis multidimensi. Di tengah upaya penanggulangan krisis, isu pemerataan mutu pendidikan tetap berkembang, baik yang digagas pemerintah maupun yang digagas masyarakat. Kunci kesuksesan sekolah unggul terletak pada aspek manajemen dan kurikulumpembelajarannya. Salah satu rekomendasi sekolah menjadi unggul di masa depan ialah sekolah harus memiliki sembilan standar yaitu: visi misi jelas, kepala sekolah profesional, guru profesional, lingkungan belajar kondusif, pendidikan berbasis ramah siswa, manajemen kuat, kurikulum luas tetapi seimbang diiringi strategi pembelajaran yang efektif, penilaian dan pelaporan prestasi siswa yang bermakna, dan pelibatan masyarakat secara positif partisipatif.
\end{abstract}

Kata kunci: Sekolah Berkualitas (Unggul), Manajemen, Kurikulum, Siswa Berkualitas (Unggul), Pendidikan Agama Islam.

\section{A. PENDAHULUAN}

Perubahan yang terjadi pada satu dekade terakhir sangatlah luar biasa di Indonesia. Salah satu dampak yang ditimbulkan adalah terjadinya krisis multidimensional yang menjadikan Indonesia terpuruk dalam segala sektor kehidupan baik politik, ekonomi, sosial, budaya, teknologi, termasuk juga di dunia pendidikan (Darmaningtyas, 1999). Tidak hanya isu kemanusiaan, politik, kesehatan, dan pendidikan yang menjadi polemik nasional, tetapi juga musibah nasional pada kasus alam seperti tsunami Aceh, gempa Jogja, lumpur Lapindo, longsor di Tenjolaya, kasus century, kecelakaan di udara, darat, dan lautan. Hilangnya pesawat Adam Air, musibah Kapal Pasopati dan Levina, kecelakaan kereta api yang berantai, demikian pula kecelakaan darat yang tiada henti-henti membentuk mata rantai kedukaan semakin membuat krisis Indonesia benar-benar sangat mengkhawatirkan. Perilaku demo yang sampai menjurus anarkis juga terjadi di banyak daerah, konflik horisontal antar daerah juga sering terjadi, termasuk konflik vertikal di pemerintahan pusat menjadi berita yang menggelisahkan masyarakat, jama'ah haji yang kelaparan di Arafah dan Mina, rakyat kelas bawah antri membeli bahan pokok makanan dan minyak tanah telah pula menjadi pemandangan sehari-hari.

Namun demikian, di tengah krisis multidimensi tersebut, ada hal-hal positif yang muncul dari arus perubahan ini. Pola pemerintahan yang sentralistik menjadi desentarlistik (Bafadal, 2007). Demokratisasi membangun transparansi

\footnotetext{
${ }^{1}$ Dosen UPI Kampus Cibiru
} 
dalam penyelengaraan negara. Begitu pula dalam hal penyelenggaraan penyelenggaraan pendidikan yang mulai melahirkan Undang-undang Republik Indonesia Nomor 20 Tahun 2003 tentang Sistem Pendidikan Nasional dan Undang-undang Republik Indonesia Nomor 14 Tahun 2005 tentang Guru dan Dosen, semua regulasi ini dimiliki setelah setengah abad bangsa Indonesia merdeka. Alam keterbukaan telah menggubah penyelenggaraan pendidikan (Tilaar, 2002). Isu terakhir yang muncul adalah pemerataan peningkatan mutu. Isu ini diiringi dengan kebijakan pemerintah dengan meningkatkan standar mutu, mulai dari Standar Pelayanan Minimal (SPM), ke Standar Sekolah Nasional (SSN), ke Standar Sekolah Internasional (SSI) atau sering pula disebut Standar Nasional Bertaraf Internasional (SNBI) (Arifin, 2006a). Di sekolah, gerakan peningkatan mutu ini juga dikenal dengan inovasi manajemen berbasis sekolah (school based management) yang intinya mendorong sekolah menjadi berkemampuan swakelola (self managing school) (Arifin, 2006b; Suderadjat, 2005).

Penyelenggaraan sekolah dimaksudkan untuk menghasilkan siswa atau lulusan yang memiliki pengetahuan, keterampilan, dan budi pekerti yang luhur serta emosi dan spiritual yang baik, sehingga mereka mampu untuk melanjutkan ke jenjang yang lebih tinggi dan dapat mengisi lapangan kerja atau memiliki jiwa kewirausahaan, terutama mampu hidup di tengah masyarakat sebagai warga negara yang baik dan berbakti (Arifin, 2006a). Dengan demikian, tujuan antara sekolah adalah mewujudkan sekolah efektif atau sekolah unggul yang pada akhirnya meningkatkan pembelajaran dan hasil belajar siswa. Oleh karena itu, pengelolaan sekolah yang unggul idealnya berorientasi pada kebutuhan sekarang dan masa depan (school basic need in the future).

\section{B. KONSEP PENDIDIKAN ISLAM}

Menurut konsep Islam, proses tarbiyah (pendidikan) mempunyai tujuan untuk melahirkan suatu generasi baru dengan segala ciri-cirinya yang unggul dan beradab. Penciptaan generasi ini dilakukan dengan penuh keikhlasan dan ketulusan yang sepenuhnya dan seutuhnya kepada Allah SWT melalui proses tarbiyah. Melalui proses tarbiyah inilah, Allah SWT telah menampilkan peribadi muslim yang merupakan uswah dan qudwah melalui Muhammad SAW. Peribadinya merupakan manifestasi dan jelmaan dari segala nilai dan norma ajaran Al-Qur'an dan sunah Rasulullah SAW. Islam menghendaki program pendidikan yang menyeluruh, baik menyangkut aspek duniawi maupun ukhrowi. Dengan kata lain, pendidikan menyangkut aspek-aspek rohani, intelektual dan jasmani. Maka hal ini, proses pendidikan sangat didukung banyak aspek, terutama guru atau pendidik, orang tua, dan juga lingkungan.

Lingkup materi pendidikan Islam secara lengkap dikemukakan oleh Heri Jauhari Muchtar dalam bukunya "Fikih Pendidikan", sebagaimana dikutip dalam Sismanto (2008), yang menyatakan bahwa pendidikan Islam itu mencakup aspekaspek sebagai berikut: Pendidikan keimanan (Tarbiyatul Imaniyah), Pendidikan moral/akhlak ((Tarbiyatul Khuluqiyah), Pendidikan jasmani (Tarbiyatul Jasmaniyah), Pendidikan rasio (Tarbiyatul Aqliyah), Pendidikan kejiwaan/hati nurani (Tarbiyatulnafsiyah), Pendidikan sosial/kemasyarakatan (Tarbiyatul 
Ijtimaiyah), Pendidikan seksual (Tarbiyatul Syahwaniyah). Secara umum, keseluruhan ruang lingkup materi pendidikan Islam yang tercantum di atas, dapat dibagi manjadi 3 materi pokok pembahasan. Ketiga pokok bahasan tersebut yakni; Tarbiyah Aqliyah (IQ learning), Tarbiyyah Jismiyah (Physical learning), dan Tarbiyatul Khuluqiyyah (SQ learning).

Pertama, adalah Tarbiyah Aqliyah (IQ learning). Tarbiyah aqliyah atau sering dikenal dengan istilah pendidikan rasional (intellegence question learning) merupakan pendidikan yang mengedapan kecerdasan akal. Tujuan yang diinginkan dalam pendidikan itu adalah bagaimana mendorong anak agar bisa berfikir secara logis terhadap apa yang dlihat dan diindra oleh mereka. Input, proses, dan output pendidikan anak diorientasikan pada rasio (intellegence oriented), yakni bagaimana anak dapat membuat analisis, penalaran, dan bahkan sintesis untuk menjustifikasi suatu masalah. Misalnya melatih indra untuk membedakan hal yang di amati, mengamati terhadap hakikat apa yang di amati, mendorong anak bercita-cita dalam menemukan suatu yang berguna, dan melatih anak untuk memberikan bukti terhadap apa yang mereka simpulkan.

Kedua, Tarbiyyah Jismiyah (Physical learning), yaitu segala kegiatan yang bersifat fisik dalam rangka mengembangkan aspek-aspek biologis anak tingkat daya tubuh sehingga mampu untuk melaksanakan tugas yang di berikan padanya baik secara individu ataupun sosial nantinya, dengan keyakinan bahwa dalam tubuh yang sehat terdapat jiwa yang sehat "al-aqlussalim fi jismissaslim" sehingga banyak di berikan beberapa permainan oleh mereka dalam jenis pendidikan ini.

Ketiga, Tarbiyatul Khuluqiyyah (SQ learning). Makna tarbiyah khuluqiyyah disini di artikan sebagai konsistensi seseorang bagaimana memegang nilai kebaikan dalam situasi dan kondisi apapun dia berada seperti; kejujuran, keikhlasan, mengalah, senang bekerja dan berkarya, kebersihan, keberanian dalam membela yang benar, bersandar pada diri sendiri (tidak bersandar pada orang lain), dan begitu juga bagaimana tata cara hidup berbangsa dan bernegara. Oleh sebab itu maka pendidikan akhlak tidak dapat di jalankan dengan hanya menghapalkan saja tentang hal baik dan buruk, tapi bagaimana menjalankannya sesuai dengan nilai nilainya. Ada beberapa bagian dalam hal ini antara lain, mengumpulkan mereka dalam satu kelompok yang berbeda karakter; Membantu mereka untuk menemukan jati dirinya dengan memberikan pelatihan, ujian, dan tempaaan; Membentuk kepribadian/mendoktrin dengan selalu menjahui hal yang jelek dan berpegang teguh terhadap nilai kebaikan.

\section{MANUSIA (SISWA) BERKUALITAS (UNGGUL) DALAM PANDANGAN AL-QUR'AN}

Berbagai konsep dilontarkan orang tentang hakikat manusia. Manusia dikatakan sebagai makhluk yang pandai menciptakan bahasa untuk menyatakan fikiran dan perasaan, sebagai makhluk yang mampu membuat alat-alat, sebagai makhluk yang dapat berorganisasi sehingga mampu memanfaatkan lingkungan untuk kepentingan manusia, sebagai makhluk yang suka bermain, dan sebagai makhluk yang beragama. Dalam al-Qur'an, manusia berulangkali diangangkat derajatnya karena aktualisasi jiwanya secara posetif, al-Qur'an mengatakan manusia itu "hanief" yaitu condong kepada kebenaran, mentauhidkan Tuhan, dan 
nilai-nilai luhur lainnya, yang banyak dibicarakan al-Qur'an tentang manusia adalah sifat-sifat dan potensinya. Dalam hal ini, ditemukan sekian ayat al-Qur'an yang dengan terang memuji dan memuliakan manusia, seperti pernyataan tentang terciptanya manusia dalam bentuk dan keadaan sebaik-baiknya (QS. at-Tiin (95): 5) dan penegasan tentang dimuliakannya makhluk ini dibandingkan dengan kebanyakan makhluk-makhluk Tuhan yang lain (QS. al-Isra (17): 70). Tetapi, di samping itu, sering pula manusia mendapat celaan Tuhan karena ia amat lalim (aniaya) dan mengingkari nikmat (QS. Ibrahim (14): 34) (Rif'at Syauqi Nawawi, 2000: 8).

Apabila ditelusuri konsep-konsep tentang jati diri manusia yang dikemukakan, maka pertanyaan bagaimanakah konsep manusia berkualitas menurut al-Qur'an. Pertanyaan ini memang sangat menarik dan menantang. Untuk menjawab pertanyaan ini terlebih dahulu mengkaji beberapa pendapat dari tokohtokoh Psikologi tentang manusia berkualitas, sebagai berikut: (1) Karen Horney (1942, seorang ahli Psikologi), mengatakan bahwa "manusia berkualitas adalah orang yang telah mampu menyeimbangkan dorongan-dorongan dalam dirinya, sehingga mewujudkan tingkahlaku yang harmonis. Ia mampu berhubungan dengan lingkungannya, mampu menciptakan suasana aman dan harmonis. Ia tidak agresif, tidak mengasingkan diri dari lingkungannya, dan hidupnya tidak pula bergantung pada orang lain". (2) Gordon Allport (1964), "manusia berkualitas dipandang sebagai orang yang telah menunjukkan kemampuan untuk memperluas lingkungan hidupnya, menghayati situasi untuk dapat berkomunikasi dengan hangat, menerima dirinya sebagaimana adanya, mempersepsi lingkungan secara realistik, memandang dirinya secara obyektif, serta berpegang pada pandangan hidup secara utuh. Ciri-ciri ini dimiliki oleh manusia yang telah matang (mature)". (3) Jourard (1980), "manusia berkualitas adalah manusia sehat yang memiliki ciri (a) membuka diri untuk menerima gagasan orang lain; (b) peduli terhadap dirinya, sesamanya serta lingkungannya; (c) kreatif; (d) mampu bekerja yang memberikan hasil (produktif); dan (e) mampu bercinta". (4) Thomas J. Peters dan Robert H.Waterman, "menamakan manusia berkualitas dilihat dari keberhasilan menjalankan usaha, adalah orang yang menampilkan ciri-ciri sebagai berikut: (a) memeiliki kegemaran untuk selalu berbuat sesuatu, dari pada banyak bertanya; (b) menampilkan hubungan yang erat dengan para rekannya; (c) bersifat otonom dan memperlihatkan kewiraswastaan; (d) membina kesadaran bahawannya untuk menampilkan upaya terbaik; (e) memandang penting keuletan dalam menjalankan usaha; (g) menempatkan orang secara proporsional; dan (h) menggunakan prinsip pengawasan yang lentur (longgar tapi ketat)".

Masih banyak tokoh lain yang telah mencoba merumuskan karakteristik manusia berkualitas, berdasarkan sudut pandang yang berbeda. Manusia berkualitas itu antara lain dinamakan sebagai integrated personality, healthy personality, normal personality, dan productive personality (M.D.Dahlan, 1990: 2-3). Lebih jauh lagi ditemukan penamaan manusia berkualitas itu sebagai insan kamil, manusia yang seutuhnya, sempurna, manusia [insan] kaffah, manusia yang hanief. Apabila memperhatikan al-Qur'an banyak sekali (tidak kurang dari 91) ayat yang berbicara tentang kejadian manusia, status manusia, martabat manusia. kesucian manusia, fitrah manusia, sifat manusia, tuags manusia, pembinaan 
manusia, penggangu manusia, kemampuan manusia, perbedaan manusia, nasib manusia, dan perjalan hidup manusia. Pembicaraan tentang manusia berkualitas, tersebar di antara ayat-ayat tersebut.

Banyak istilah yang digunakan al-Qur'an dalam menggambarkan manusia berkualitas atau makhluk yang diciptakan Allah dalam sosok yang paling canggih, di antaranya kata manusia beriman [al-Hujarat (49: 14, dll] dan beramal saleh (QS. at-Tiin (95): 6, dll), diberi Ilmu (al-Isra (17): 85, Mujadalah : 11, Fathir: 28, dll), alim (al-Ankabut (29): 43, dll), berakal (al-Mulk (67): 10, dll), manusia sebagai khalifah (QS.al-Baqarah (2): 30,dll), jiwa yang tenang (QS. al-Fajr (89): 27-28, dll), hati yang tenteram (al-Ra'd (30): 28, dll), kaffah (al-Baqarah (2): 208, dll), muttaqin (al-Baqarah (2): 2, dll), taqwa (al-Baqarah (2): 183, dll) , mu'minin, muhsinin, syakirin, muflihin, shalihin, yang kemudian diberi keterangan untuk mendeskripsikan ciri-cirinya. Istilah-istilah tersebut saling berkaitan dan saling menerangkan. Jadi, apabila mengambil salah satu istilah dari istilah-istilah yang digunakan al-Qur'an, maka deskripsinya akan saling melengkapi dan merupakan ciri bagi yang lainnya. Dapat dikatakan bahwa konsep dan karakteristik manusia berkualitas tidak tunggal, akan tetapi komprehensif dan saling melengkapi.

"Jelaslah bahwa manusia berkualitas hendaknya menampilkan ciri sebagai hamba Allah yang beriman, sehingga hanya kepada Allah ia bermunajah, serta memberikan manfaat bagi sesamanya. Sekirannya lebih dalam ditelusuri, kedua ciri utama itu kita dapatkan pada manusia taqwa, sehingga manusia berkualitas dapat pula diartikan sebagai manusia yang beriman dan bertaqwa" (M.D.Dahlan,1990: 7), artinya manusia yang berperilaku tawakkal, pemaaf, sabar, muhsin, mau bersyukur, berusaha meningkatan kualitas amalnya dan mengajak manusia lain untuk beramal. Untuk itu, keutamaan manusia berpangkal pada adanya iman kepada Allah dan keimannya diwujudkan dalam perilaku yang memberi manfaat bagi masyarakat, berilmu pengetahuan, dan beramal saleh.

Djamaludin Ancok [1998: 12], mengutip Hartanto [1997], Raka \& Hendroyuwono [1998], ada empat kapital, yaitu kapital intelektual [intelect capital], kapital sosial [social capital], kapital lembut [soft capital], dan kapital spritual [spritual capital]. Empat kapital yang dikemukan ini juga menggambar ciri manusia berkualitas. Maka, karakteristik yang dikemukakan al-Qur'an, menurut hemat pemakalah menjadi tolak ukur kualitas manusia, karena karakteristik tersebut diturunkan dari konfigurasi nilai-nilai yang dikemukakan alQur'an yang hadir bersama dengan kelahiran manusia ke dunia, dan menjadi sifat penentu dalam pembentukan kepribadian manusia, yaitu kualitas iman, ilmu pengetahuan, kualitas amal saleh, dan kualitas sosial.

\section{Kualitas Iman}

Keimanan merupakan kebutuhan hidup manusia, menjadi pegangan keyaninan dan motor penggerak untuk perilaku dan amal manusia. Iman sebagai syarat utama dalam mencapai kesempurnaan atau insan utama, dan merupakan langkah awal untuk menuju keshalihan dan mewujudkan perilaku, amal saleh dan pengorbanan manusia bagi pengabdian kepada Allah, karena iman juga sangat terkait dengan amal saleh. Dalam keadaan beriman, manusia dapat memperlihatkan kualitas perilaku, kualitas amal salah, dan kualitas sosialnya yaitu ketulusan dalam kehidupan pribadi maupun kehidupan masyarakat luas. Manusia 
akan berperilaku, bekerja, dan bermasyarakat sesuai dengan fitrah kejadiannya yang condong kepada hanief. Manusia berkualitas akan berjuang melawan penindasan, tirani, dan tidak membiarkan kediktatoran atau tindakan sewenangwenang. Karena imam memberikan pula kedamaian jiwa, kedaimaian berperilaku, dan kedaiaman beramal saleh. Djamaludin Ancok [1998: 15], pada pembahasan kapital spritual, mengatakan bahwa "semakin tinggi iman dan taqwa seseorang semakin tinggi pula kepital Intelektual, kapital sosial, dan kapital lembut". Manusia yang beriman hatinya akan dibimbing Allah, jiwanya menjadi tenang dalam melakukan aktivitas hidupnya, dalam QS.at-Taghaabun: 11, Allah berfirman: ..."Siapa yang beriman kepada Allah, Allah akan memimpin hatinya" [QS.64: 11].

\section{Kualitas Intelektual}

Kualitas intelektual sudah menjadi potensi awal manusia, karena ketika manusia diciptakan, "Allah mengajarkan kepada Adam segala nama benda" [QS.al-Baqarah (2): 31]. Untuk itu, manusia sejak lahir telah memiliki potensi intelektual, kemudian potensi intelektual ini dikembangkan. Kualitas intelektual merupakan perangkat yang sangat diperlukan untuk mengolah alam ini. Rasulullah bersabda "barang siapa yang ingin memperoleh kebahagian dunia, dengan ilmu dan barang siapa yang ingin memperoleh kebahagian akhirat, dengan ilmu dan barang siapa yang ingin memperoleh kebahagian keduanya juga dengan ilmu".

Dalam al-Qur'an surat Mujadalah ayat 11, Allah mengangkat derajat orang yang memiliki ilmu pengetahuan: "Allah mengangkat orang-orang yang beriman dari golonganmu semua dan juga orang-orang yang dikaruniai ilmu pengetahuan hingga beberapa derajat". Kemudian dalam firman Allah QS. Zumar: 9, Allah memberi perbedaan orang yang berilmu pengetahuan dan orang yang tidak memiliki ilmu pengetahuan, sebagai berikut: "Katakanlah: Adakah sama orangorang yang berilmu pengetahuan dan orang-orang yang tidak berimu pengetahuan".

Ilmu pengetahuan dibutuhkan manusia guna menopang kelangsungan peradabannya, karena manusia diamanatkan Allah untuk mengolah dan memberdayakan alam ini. Oleh karena itu, ilmu yang dimiliki manusia menghantarkan manusia ketingkat martabat yang lebih tinggi bila dibandingkan dengan makhluk ciptaan Allah yang lain. Al-Qur'an, memberikan derajat yang tinggi bagi manusia yang memiliki ilmu pengetahuan, dan memberikan perbedaan yang jelas antara manusia yang memiliki ilmu pengetahuan dan yang tidak memiliki ilmu pengatahuan.

Perbedaan antara manusia berimu dan tidak berimu dalam al-Qur'an, memberikan pejalaran bahwa "segala kejadian yang berlangsung, senantiasa dikembalikan kepada orang-orang yang berilmu pengetahuan (ahlinya), bahkan martabat mereka itu disusulkan setingkat kemudian sesudah martabat pada nabi dalam mangkasyafkan hukum Allah Ta'ala" [Muhammad Jamaluddin Alqasimi Addimasyqi, 1973: 15]. Djamaludin Ancok [1998: 12], mengatakan bahwa "kapital intelektual adalah perangkat yang diperlukan untuk menemukan peluang dan mengelola ancaman dalam kehidupan. Banyak pakar yang mengatakan bahwa kapital intelektual sangat besar peranannya di dalam menambah nilai suatu 
kegiatan". Untuk itu, Ilmu pengetahuan telah menjadikan manusia dengan berbagai keahlian (ahliha). Tiap keahlian menjadi unsur penyempurna dalam perakitan kehidupan sosial. Tiap aspek sosial yang tidak dikaji oleh bidang ilmunya yang sesuai akan menimbulkan usaha yang di luar kontrol nilai sosial, dan besar kemungkinan dapat mengakibatkan terjadinya ketidakharmonisan [kerusakan] di bumi. Oleh karena itu, menempatkan ahli dalam suatu bidang kehidupan tertentu menjadi jaminan keadilan bagi kehidupan kemanusiaan [Ahmad Muflih Saefuddin,1992: 6].

\section{Kualitas Amal Saleh}

Amal saleh adalah pembentukan kualitas manusia, sebab tiap kerja yang dilakukan setiap saat merupakan ukiran kearah terbentuk kepribadian manusia. Amal saleh sebagai pengejawantahan iman, maka suatu pekerjaan yang dilakukan harus memiliki orientasi nilai. Ini berarti sistem keimanan teraktualisasi melalui kerja amal saleh, karena kerja semacam ini memilik dimensi yang abadi. AlQur'an surat at-Tiin ayat 5-6, menyampaikan bahwa "manusia akan dikembalikan kekondisi yang paling rendah, kecuali manusia yang beriman dan mengerjakan amal salah".

Amal saleh merupakan perbuatan yang bernilai bagi manusia, dan itu pula yang akan dilihat dalam cermin hidupnya. Menurut Ahmad Muflih Saefuddin [1992: 7] bahwa, "amal terwujud di kala mereka memiliki ilmu pengetahuan. Tanpa ilmu pengetahuan tidak terwujud perbuatan yang memiliki makna bagi kehidupan manusia. Amal tidak terwujud jika tidak ada sikap percaya dalam dirinya, karena keraguan tidak dapat mewujudkan perbuatan".

Oleh karena itu, amal perbuatan yang bermakna bagi kehidupan manusia, baru dapat terwujud apabila sebelumnya ada iman dan ilmu pengetahuan. Karena dengan beriman memberikan kelapangan terhadap penderitaan, memberikan kelapangan dalam beramal. Dengan demikian Iman dapat membentuk kekuatan dalam diri manusia untuk dapat mengubah penderitaan menjadi kebahagiaan, memberikan semangat kerja. Selain itu, amal saleh juga terkaitan dengan kualitas ilmu, karena dengan berilmu manusia memiliki orientasi kesanggupan melakukan perbaikan dan melakukan sesuatu perbuatan amal untuk kepentingan dan kemaslahatan manusia.

\section{Kualitas Sosial}

Manusia sebagai makhluk sosial berfungsi terhadap masyarakatnya, artinya memiliki kemampuan untuk melakukan hubungan dengan orang lain, karena manusia merupakan keluarga besar, yang berasal dari satu keturunan Adam dan Hawa. Selain itu, Allah menjadikan manusia dalam berbangsa-bangsa dan bersuku-suku, agar mereka saling interaksi untuk saling mengenal dan tolong menolong dalan berbuat kebaikan dan bertaqwa.

Sifat sosial yang dimiliki manusia sesuai dengan fitrahnya, yaitu adanya kesedian untuk melakukan interaksi dengan sesamanya. Dalam al-Qur'an, bahwa "manusia selalu mengadakan hubungan dengan Tuhannya dan juga mengadakan hubungan dengan sesama manusia". Selain itu dalam al-Qur'an surat al-Maidah ayat 2: bahwa manusia dalam melakukan aktivitas sosial sifat yang terbangun adalah saling "tolong menolong-menolong dalam kebaikan dan taqwa, dan 
dilarang tolong-menolong dalam berbuat maksiat, berbuat kejahatan". Maka, kualitas sosial sangat terkait dengan kualitas iman, ilmu, dan amal selah.

Djamaludin Ancok [1998: 13], juga mengatakan bahwa intelektual Kapital baru akan tumbuh bila masing-masing orang berbagai wawasan. Untuk dapat berbagi wawasan orang harus membangun jaringan hubungan sosial dengan orang lainnya. ... Semakin luas pergaulan seseorang dan semakin luas jaringan hubungan sosial [social networking] semakin tinggi nilai seseorang. "Kapital sosial dimanifestasikan pula dalam kemampuan untuk bisa hidup dalam perbedaan dan menghargai perbedaan [diversity]. Pengakuan dan penghargaan atas perbedaan adalah suatu syarat tumbuhnya kreativitas dan sinergi. Kemampuan bergaul dengan orang yang berbeda, dan menghargai dan memanfaatkan secara bersama perbedaan tersebut akan memberikan kebaikan buat semua".

Dalam al-Qur'an, mamusia diciptakan dalam berbangsa-bangsa dan bersuku-suku agar saling kenal mengal, saling tolong-menolong. Dengan dasar ini, manusia membangun jaringan silahturrahmi antara sesamanya sesuai dengan fitrahnya. Karena dengan jaringan silaturrahmi akan memberikan kebaikan yaitu manusia dapat membangun ukhuawah antar semamanya, dengan silahturrahim antar semasamanya tercipta atau terbuka peluang-peluang yang lain, apakah berupa pengalaman, pengetahuan, amal, dan memperkuat ikatan persaudaraan yang dibangun atas dasar iman untuk menuju muara taqwa. Maka, manusia sebagai makhluk sosial sangat membutuhkan jaringan sosial, untuk membangun persaudaraan yang abadi.

\section{UPAYA PENDIDIKAN ISLAM DALAM MEMBENTUK MANUSIA (SISWA) BERKUALITAS (UNGGUL)}

Pembicaraan tentang manusia, merupakan kunci yang paling strategis dalam upaya membangun menuju masyarakat madani Indonesia. Maka, konsep dan proses pendidikan dalam hal ini pendidikan Islam, harus dapat melihat kedudukan manusia sebagai subjek didik yang memiliki potensi untuk diberdayakan dan dikembangkan, artinya pendidikan merupakan proses humanisasi dengan menghargai segala potensi yang dimiliki manusia. Proses humanisasi dalam pendidikan, dimaksudkan sebagai upaya megembangkan manusia sebagai makhluk hidup yang tumbuh dan berkembang dengan segala potensi [fitrah] yang ada padanya. Manusia dapat dibesarkan [potensi jasmania] dan diberdayakan [potensi rohaniah] agar dapat berdiri sendiri serta dapat memenuhi kebutuhan hidupnya.

Dalam proses humanisasi, berarti menusia bukan hanya sekedar memenuhi kebutuhan biologisnya saja, tetapi juga ia harus bertanggungjawab terhadap dirinya sendiri dan terhadap kesejahteraan masyarakatnya [H.A.R. Tilaar, 2002: 171]. Maka dalam konteks ini, "manusia harus belajar untuk bertanggungjawab, mengenal dan menghayati serta melaksanakan nilai-nilai moral [knowing is doing], sebab tanpa tanggungjawab dan melaksanakan nilai-nilai moral tidak mungkin akan tercipta suatu masyarakat yang aman dan tenteram di mana kepribadian dapat berkembang”. Dalam al-Qur'an, manusia dianggap sebagai makhluk yang memiliki potensi yang tidak terbatas, sebagai makhluk Allah yang paling sempurna [QS. 32: 7], memiliki potensi [fitrah] bawaan [QS.30: 30] yang 
tidak terbatas, dapat diberdayakan, dapat dididik dan mendidik [melakukan proses mengajar] sehingga manusia menjadi makhluk terdidik dan berkualitas dalam kehidupnya.

Proses humanisasi "merupakan proses yang terbuka, di mana manusia diberdayakan dan dioptimalkan potensi [fitrah] bawaannya sehingga manusia dapat menguasai ilmu pengetahuan, keterampilan, teknologi serta penerapannya dan penghayatan pada seni serta budaya, dan sebagainya”. Ini berarti, peran dan fungsi pendidikan sangat senteral dalam upaya proses humanisasi tersebut. Pendidikan dalam hal ini pendidikan Islam, harus dapat meletakkan kedudukan manusia sebagai subjek dalam proses pembinaan dan pengembangan potensi [fitrah] bawaannya. Dengan demikian dalam proses humanisasi, sangat dibutuhkan konsep pendidikan yang betul-betul dapat memberi gambaran yang komprehensip sebagai solusi dalam upaya memanusiakan manusia [humanisasi] dengan menekankan keharmonisan hubungan baik sesama manusia, masyarakat, maupun dengan lingkungan yang didasarkan pada nilai-nilai normatif ilahiyah.

Pendidikan dalam konsep Islam sebenarnya telah menetapkan dasar dan bertujuan untuk membangun manusia sebagai insan kamil, yaitu manusia paripurna, integral, totalitas dalam membangun hidup dan kehidupannya. Pendidikan Islam, meletakan kedudukan manusia sangat senteral sebagai subjek didik dalam upaya pembinaan dan pengembangannnya. Proses pendidikan berusaha untuk "melatih sensibilitas manusia [peserta didik] sedemikian rupa, sehingga dalam perilaku mereka terhadap kehidupan, langkah-langkah dan keputusan, begitu pula pendekatan mereka terhadap semua ilmu pengetahuan diatur dan didasarkan pada nilai-nilai etika Islam. Mereka akan terlatih dan secara mental yang sangat disiplin, sehingga pengetahuan yang dimiliki bukan hanya untuk pemuasan rasa ingin tahu intelektuan atau untuk manfaat yang sifat duniawi, tetapi juga untuk tumbuh sebagai makhluk rasional, makhluk yang berbudi, bermoral dan spiritual dalam kehidupannya secara menyeluruh bagi kesejahteraan masyarakat dan umat manusia. Proses pendidikan harus berupaya mengembangkan manusia agar memiliki pengetahuan, keterampilan, spritual, dan berpikir rasional, sehingga tumbuh perilaku manusia yang mencintai demokrasi, perdamaian, hidup selaras, stabil, berbudi dan berbudaya sebagai makhluk Tuhan dan makhluk sosial yang hidup bersama manusia lain dengan tujuan memakmurkan, mengontrol dan mengatur alam semesta berdasarkan otoritas Tuhan. Artinya proses pendidikan Islam akan menghasilkan manusia yang beramal ilahiyah dan berilmu ilahiyah sebagai manusia yang berkualitas [insan kamil]. Dengan dasar ini, pengembangan konsep dasar pendidikan Islam harus bersumber dari konsep ilahiyah [ketuhanan], konsep insaniyah [humanisme] dan konsep lingkungan yang integratif dan seimbang.

A. Malik Fadjar, menyatakan bahwa manusia sebagai makhluk pengemban atau pemegang amanah khalifahan mempunyai potensi yang luar biasa besarnya, sehingga dapat mendayagunakan alam dan sesama manusia dalam rangka membangun peradaban berdasarkan nilai-nilai ilahiyah. Potensi [fitrah] bawaan manusia itu, menyangkut dengan potensi ilahiyah [ketuhanan] dan potensi kehidupan yang dilengkapi dengan hati nurani, akal pikirannya [cipta], rasa, karsa, serta dilengkapi dengan kemampuan kebebasan. Manusia juga memiliki 
kemampuan kebebasan untuk berbuat sesuatu sesuai dengan pilihan-pilihannya [taqwa dan fujur] yang dapat dipertanggungjawabkan sebagai makhluk individu dan makhluk sosial, makhluk fungsional, makhluk bercirikan etika-religius, makhluk berbudaya, yang kesemuanya itu merupakan nilai-nilai yang akan terkonstruksi dalam hidup dan kehidupan manusia itu sendiri.

Manusia sebagi makhluk Tuhan yang memiliki potensi [fitrah] bawaan ini bersifat integral-holistik. Dengan demikian pengembangan sistem pendidikan harus berorientasi kepada potensi [fitrah] tersebut, baik menyangkut dengan potensi ukhrawi dan duniawi sekaligus secara integral. Pengembangan sistem pendidikan Islam tidak hanya berorientasi kepada persoalah ukhrawi [akhirat] saja, tetapi harus terintegrasi dengan persoalan-persoalan duniawi, seperti ilmu pengetahuan, teknologi, seni, budaya, sosial kemasyarakatan, dan sebaginya. Apabila konsep pendidikan Islam dapat mengintegrasikan persoalan ukhrawi dengan duniawi, maka konsep pendidikan Islam akan tampil berbeda dengan konsep pendidikan lainnya, karena secara integratif dapat mengembangkan pendidikan ukrawiyah dan duniawiyah secara integral sekaligus. Pandangan ini, didasarkan pada konsep ajaran Islam, bahwa ajaran Islam "tidak menghendaki penghayatan agama yang mengarah pada pelarian diri dari kehidupan duniawi, tetapi bahkan sebaliknya, Islam mengajarkan asketisme duniawi, yaitu memakmurkan dan memajukan kehidupan dunia, tanpa tenggelam dalam kenikmatan semu”.

Uraian di atas, menegaskan bahwa dalam sistem pendidikan Islam "manusia dipahami sebagai zat theomorfis, maksudnya, manusia berorientasi untuk menjadi pribadi yang bergerak di antara dua titik ekstrem yaitu antara taqwa dan fujur, antara Allah dan setan dan manusia juga memiliki kehendak bebas. Artinya, manusia mampu membentuk nasibnya sendiri dan bertanggungjawab, sehingga manusia mampu menerima amanah khusus dari Allah”. Qur'an memberikan gambaran, bahwa para malaikat bersujud kepadanya [Adam], karena ia memiliki potensi yang integral, sehingga manusia mampu menjadi khalifah fil ardli. Allah menciptakan dan melengkapi manusia dengan potensi atau daya-daya yang ada dalam dirinya, kemudian perkembangan selanjutnya terserah pada manusia sendiri dan manusia dapat menentukan nasibnya sendiri. Tugas manusialah yang dapat memberdayakan potensi-potensi tersebut, karena dayadaya untuk mewujudkan kehendak itu telah ada dalam diri manusia sebelum ada perbuatan. Maka dari sini, posisi dan peran pendidikan dalam sistem pendidikan Islam adalah sangat senteral untuk memberdayakan dan mengaktualisasikan potensi fitrah, melalui pendidikan sehingga memperoleh ilmu pengetahuan, teknologi, keterampilan, seni dan budaya berdarkan nilai-nilai ilahiyah.

Dalam al-Qur'an, Allah telah memberikan postulat-postulat atau aksioma sebagai kunci dalam memahami, mengembangkan, dan memberyagunakan manusia, antara lain: [1] Allah telah memerintahkan manusia agar senantiasa berpikir dan menggunakan akal pikirannya dalam memcahkan persoalanpersoalan hidup yang dihadapi, seperti berpolitik, ekonomi, pendidikan dan lain sebagainya. Ini artinya, Allah telah menyediakan potensi [fitrah] pada manusia untuk diberdayakan, sehingga menjadi manusia yang fungsional. [2] Allah telah melakukan liberalisasi dalam bidang ilmu dan semua manusia [khususnya 
muslim] baik laki-laki maupun perempuan diwajibkan mencari ilmu kepada siapa saja dan di mana saja [Hadits]. [3] Dengan potensi akal, manusia diperintahkan untuk membuktikan kekuasaan Allah dengan cara mengkaji dan mengolah alam demi keperluan hidupnya dan dilarang berbuat semena-mena, kerusakan dan pertumpahan darah. Allah telah memberikan pertanyaan-pertanyaan penting dalam al-Qur'an tentang potensi-potensi besar yang ada di darat, laut dan angkasa. Al-Qur'an memberikan postulat-postulat atau aksioma sebagai kunci bagi manusia untuk memahami dan mendayagunakan alam. [4] Manusia diperintahkan untuk fantasirun fil ardl [mengembara di muka bumi] dalam rangka mencari ilmu pengetahuan. Ini artinya, setiap manusia, masyarakat, dan bangsa, oleh Allah diberi keistimewaan masing-masing, ilmu pengetahuan dan perkembangan pemikiran umat manusia tidak berhenti. [5] Kecintaan terhadap informasi atau pengetahuan yang akhirnya menumbuhkan kecintaan kepada kegiatan belajar. AlQur'an pada ayat pertama kali turun adalah perintah iqra', mengandung perintah untuk membaca dan belajar yang berorientasi pada upaya mengkaji tentang hakekat Tuhan [ilahiyah], mengkaji hakekat manusia [insaniyah], mengkaji penomena-penomena alam semesta [sunatullah], dan hubungan antara ketiganya serta fungsinya masing-masing secara terus menerus dalam rangka mewujudkan manusia dan masyarakat yang berkualitas dan terbaik dalam kehidupan.

Uraian di atas, menegaskan bahawa dengan potensi [fitrah] tersebut, manusia memiliki kecenderungan untuk dibina dan dikembangkan sesuai dengan potensinya, karakteristiknya dan hakekat kemanusian, sehingga dapat fungsional dalam kehidupan yang betul-betul eksis sebagai pemegang amanah khalifah fil ardl. Untuk itu, pendidikan yang berdasarkan konsep dasar pendidikan Islam, harus memandang manuasi sebagai makhluk pemegang amanah khalifah fil ardl, manusia dapat didik, dilatih dan diberdayakan untuk melahirkan manusia beriman, manusia yang sempurna, bermoral tinggi [anggung dalam moralnya], memiliki pengetahuan, berwawasan luas, sebagai manipestasi dari liberalisasi Allah terhadap kewajiban seorang muslim untuk menuntut ilmu. Hal ini diujudkan dengan perintah Allah untuk membaca [iqra'] dan fantasirun fil ardl dalam rangka eksplorasi ilmu pengetahuan. Selain itu, manusia juga berkemampuan untuk mengintegrasikan nilai-nilai spritual ilahiyah dengan nilai-nilai kultural duniyawiyah dalam konstruksi yang kokoh, seimbang, harmonis, dinamis dan kreatif dalam kehidupan manusia. Dengan demikian, potret manusia semacam inilah yang dikehendaki dalam bangunan pendidikan Islam berdasarkan konsep potensi [fitrah] yang bernilai ilahiyah yang aktual dalam hidup dan kehidupan manusia.

Pengembangan pendidikan, harus tetap memperhatikan aspek potensi dasar manusia yang ideal dan fungsional tersebut, karena semua potensi yang dimiliki manusia akan menjadi sasaran pendidikan untuk dikembangkan melalui kondisi-kondisi yang diciptakan dengan memberikan rangsangan sesuai dengan kondisi yang diinginkan dan dikehndaki. Kondisi ini mungkin saja dapat mempengaruhi potensi, baik yang tercipta melalui proses alamiah maupun situasi yang diciptakan dalam proses pendidikan. Dengan pengembangan potensi tersebut, memungkinkan manusia tumbuh dan berkembang secara utuh, harmonis, integratif sesuai dengan nilai-nilai dan hakekat humanisasi. Maka, melalui proses 
pendidikan, dapat "menimbulkan pertumbuhan yang seimbang dari kepribadian total manusia melalui latihan spritual ilahiyah, intelek, rasional diri, perasaan dan kepekaan terhadap perkembangan manusia. Karena itu, proses pendidikan seharusnya menyediakan dan menciptakan jalan bagi pertumbuhan manusia dalam segala aspeknya, yaitu aspek spritual ilahiyah, intelektual, imaginatif, fisikal, ilmiah, linguistik”, baik secara individual maupun secara kolektif serta dapat memotivasi semua aspek tersebut untuk mencapai kebaikan dan kesempurnaan manusia [insan kamil].

Sejalan dengan pandangan di atas, maka pendidikan sesuai dengan fungsi dan perannya diharapkan mampu melahirkan manusia dan masyarakat yang memiliki kemampuan spritual, berilmu, bermoral, memiliki kemampuan profesional, kemampuan inovasi dalam membangun dan menata kehidupan dunia yang rahmatan lil 'alamin. Usman Abu Bakar, menyatakan bahwa output pendidikan Islam sekurang-kurangnya diharapkan mampu melahirkan manusia yang memiliki kemampuan spritual ilahiyah yang tinggi, ketinggian ilmu, memiliki komitmen terhadap profesionalisme, memiliki akhlak al-karimah, yaitu akhlak terhadap dirinya, akhlak terhadap Allah Sang Pencipta-Nya dan akhlak terhadap makhluk-Nya yang mencerminkan "keanggunan moralitas" manusia dalam keluarga, masyarakat dan berbangsa yang merupakan ciri masyarakat madani. Jadi manusia dan masyarakat yang berkualitas adalah manusia dan masyarakat yang melakukan liberalisasi dalam bidang berpikir dan ilmu pengetahuan. Masyarakat dan bangsa yang tidak menganggap dirinya paling maju, bangsa yang terbuka untuk menerima ilmu dari mana saja, bangsa agresif dan mendunia. Bukan bangsa yang tertutup, arogan, dan mengaggap ilmu orang lain sebagai ilmu sekuler, ilmu kafir, dan sebagainnya”.

Dari uraian di atas, dapat disimpulkan bahwa "manusia” dan "masyarakat" yang berkualitas dalam masyarakat madani Indonesia, yaitu: [1] Manusia dalam menjalankan hidupnya merupakan pengabdian kepada Allah semata [QS.51: 56], karena Islam mengajarkan hidup dan seluruh aspeknya harus diniatkan sebagai pengabdian [ibadah] kepada Allah. [2] Cara terbaik untuk mendapatkan prestasi dalam hidup ini adalah dengan mempunyai ilmu dan memiliki etos kerja yang tinggi. Rasulullah Saw, bersabda yang artinya: "Barang siapa menghendaki kebahagian kehidupan dunia haruslah dengan ilmu dan barang siapa menghendaki kebahagian akhirat haruslah dengan ilmu dan barang siapa menghendaki kebahgian keduanya haruslah dengan ilmu pula” [al-Hadis]. [3] Berorientasi ke masa depan, kerja keras, teliti, hati-hati, menghargai waktu penuh rasa tanggungjawab dan berorientasi pada prestasi [achievement oriented] dan bukan prestige semata. Jadi, manusia dan masyarakat yang berkualitas yang dikehendaki dalam kehidupan masyarakat madani adalah manusia yang: [a] memiliki ilmu pengetahuan, teknologi, seni, budaya, untuk peningkatan derajat dan martabatnya, [b] mempunyai cita-cita, visi dan misi, dalam kehidupan, [c] memiliki keberkualitasan kompetitif, komporatif, dan keberkualitasan inovatif, [d] taat hukum, menghargai hak asasi manusia, dan menghargai perbedaan [pluralisme], [e] memiliki rasa tanggungjawab, karena "semua masalah dalam kehidupan harus dihadapi dengan penuh rasa tanggungjawab [responsibility] dan penuh perhitungan [accountability], [f] bersikap rasional, menghargai waktu, 
memperhatikan masa depan [membuat perencanaan hidup] dan perubahan, kreatif dan berkarya execelence, sehingga tercipta "manusia madani" dalam arti manusia yang mengota, elite, dan berbudaya tinggi.

Secara umum dapat dikatakan, bahwa manusia berkualitas adalah manusia yang memiliki ciri sebagai hamba Allah yang beriman, berilmu pengetahuan dan keterampilan, yang dapat memberikan manfaat bagi sesama manusia. Ketiga ciri utama ini didapatkan pada manusia yang taqwa, sehingga manusia dan masyarakat berkualitas dapat pula diartikan sebagai manusia yang beriman, bertaqwa kepada Allah Swt dengan memiliki sikap tawakkal, sabar, pemaaf, muhsin, dan selalu mau bersyukur. Manusia yang berusaha meningkatkan diri dengan memiliki pengetahuan dan keterampilan, memiliki kemampuan inovasi, kemampuan melakukan perubahan serta mengajak orang untuk meningkat. Tuntutannya, peranan pendidikan dibutuhkan untuk mensosialisasikan nilai-nilai tersebut dalam rangka mewujudkan manusia dan masyarakat Indonesia yang berkualitas, sehingga keberadaannya secara fungsional menjadi pemeran utama bagi terwujudnya tatanan dunia yang rahmatan lil 'alamin dalam kehidupan masyarakat madani Indonesia yang demokratis.

\section{E. PANDANGAN PENYELENGGARAAN SEKOLAH PADA UMUMNYA}

Pendidikan merupakan suatu usaha untuk mencerdaskan kehidupan bangsa sebagaimana tercantum dalam Pembukaan dan Batang Tubuh UUD 1945 dan GBHN. Implementasi pendidikan ini tidaklah lepas dari konteks nasional maupun internasional karena pendidikan merupakan suatu upaya untuk menyiapkan peserta didik agar dapat mengantisipasi perubahan global yang terjadi. Oleh karena itu, pendidikan harus sejalan dengan perkembangan atau perubahan global yang sedang dan akan terus berlangsung. Dengan demikian, sistem pendidikan harus selalu diperbaharui sesuai dengan tuntutan jaman.

\section{Tantangan dan Strategi}

Untuk mencapai tujuan pendidikan sebagaimana disinggung di atas, maka perlu diperhatikan tiga sasaran pendidikan. (1) Kualitas, komitmen untuk mendapatkan hasil terbaik dalam pelayanan pengajaran bagi peserta didik, dengan kata lain pendidikan berorientasi mutu. (2) Pemerataan, pemberian pelayanan merata bagi peserta didik, dengan tetap memperhatikan potensi individu, individual differencies. (3) Efisiensi dan efektivitas, efisien dalam penggunaan dana dengan sumber-sumber yang tersedia untuk mencapai keefektivan atau kualitas layanan terbaik dan merata bagi peserta didik, tanpa ada deskriminatif dalam segala aspek. Percepatan laju perubahan pada dekade akhir-akhir ini, terutama isu globalisasi pendidikan berbasis mutu, memunculkan tagihan pada berbagai usaha penyiapan tenaga terampil dan profesional yang mampu bersaing di tingkat regional maupun internasional. Untuk menyiasati pencapaian tuntutan global tersebut, maka sekolah masa depan yang berorientasi keunggulan keberadaannya tidak dapat dielakkan, meskipun pengembangannya dilakukan secara bertahap.

Sekolah masa depan harus didukung oleh prasarana yang memadahi dan penyelenggaraan pendidikan bertumpu pada pencapaian kualitas, pemerataan dan efektivitas-efesiensi. Oleh karena itu sekolah harus memiliki ciri-ciri: (1) visi dan 
misi yang jelas, (2) tujuan yang jelas dan pasti, (3) murid-murid mempunyai harapan yang tinggi, (4) memberikan pengakuan dan penghargaan bagi anggota jajaran sekolah yang telah berprestasi, dan (5) seluruh anggota jajaran sekolah menunjukkan dedikasi, komitmen, dan disiplin yang tinggi (Sergiovanni dalam Arifin, 2007). Selain itu, sekolah masa depan harus memiliki parameter keberhasilan pencapaian akademis yang terukur, menciptakan stabilitas sekolah sebagai lingkungan belajar yang prestisius, menggunakan secara penuh dan efektif sumber-sumber yang ada di sekolah dan masyarakat, peningkatan kualitas pendidik dan staf administrasi secara terus menerus, dan melibatkan masyarakat terutama orang tua murid untuk ikut bertanggung jawab dalam peningkatan wawasan masa depan peserta didik. UNESCO (2006) menggagas sekolah masa depan memiliki manajemen yang mandiri dan swakelola secara profesional, keterlibatan masyarakat yang positif-partisipatif, kurikulum dan pembelajaran disertai lingkungan belajar-mengajar yang kondusif sehingga memungkinkan terberdayanya warga sekolah bertumbuh secara positif.

Menurut Suderadjat (2005), sekolah harus merupakan bagian terpadu dari sumber daya manusia secara menyeluruh. Untuk itu, harus ada upaya untuk mengadakan kerjasama dengan lembaga pemerintahan, kemasyarakatan, penelitian, ilmu pengetahuan, hukum dan sebagainya. Pemanfaatan para profesional sebagai sumber belajar menunjukkan kepada siswa bahwa pengetahuan dapat digali dari berbagai sumber. Di sisi lain, keberhasilan usaha pendidikan tidak lepas dari upaya pencegahan masalah-masalah yang timbul dari peserta didik seperti: kesehatan, kejiwaan, penyimpangan prilaku, vandalisme, dan sebagainya. Usaha pencegahan tentu harus dilakukan secara sinergis oleh sekolah-pemerintah-masyarakat (Arifin, 2007).

\section{Tantangan yang Dihadapi}

Untuk mencapai tujuan tersebut harus dilakukan upaya identifikasi masalah atau tantangan yang berkaitan dengan pencapaian tujuan sebuah sekolah. Tantangan pertama adalah sistem pendidikan dan kurikulum yang berlaku sekarang ini. Sistem pendidikan memungkinkan penyelenggaraan pendidikan mandiri yang dikelola oleh sekolah selama masih berada dalam koridor kurikulum nasional yang berlaku. Kurikulum sekolah yang disebut Kurikulum 2006 atau Kurikulum Tingkat Satuan Pendidikan (KTSP) saat ini sudah cukup memadai karena ada kebebasan dalam mengembangkan kurikulum sesuai dengan kebutuhan lokal dan berbasis pada sekolah (School building). Pengembangan inilah yang dapat dijadikan sebagai kekhasan pada setiap sekolah. Kekhasan atau keunikan yang dibangun secara mandiri oleh sekolah dalam bentuk kurikulum yang bernafaskan keagamaan, budaya lokal, seni, kebahasaan, dan Iptek.

Tantangan kedua adalah pelaksanaan proses pembelajaran. Pada umumnya sekolah di Indonesia masih berorientasi pada penekankan "output", hasil belajar dengan nilai tinggi di bidang akademik, sebagai akibat tuntutan pemerintah dalam penyelenggaraan Ujian Nasional (UN). Dampaknya, proses pembelajaran pada umumnya menekankan pada kegiatan yang melatih siswa untuk mendapatkan nilai yang tinggi dengan usaha banyak mengerjakan soal-soal latihan dan menghafal. Padahal belajar adalah suatu proses untuk mendapatkan pengetahuan dan menggunakannya dalam kehidupan sehari-hari. Dengan kata 
lain, hasil akhir pendidikan bukan hanya pada perolehan belajar akademik, melainkan juga untuk pembentukan perilaku, kepekaan sosial, dan spiritualitas yang baik. Oleh karena itu, proses pembelajaran harus mengacu pada proses pembentukan tersebut tanpa melupakan hasil belajar yang tinggi. Kombinasi antara proses dan hasil inilah yang harus dijadikan salah satu keunggulan sekolah di masa depan. Pendekatan pengajaran yang berpusat pada guru, "teachers center", harus diubah menjadi "children center". Pada "children center" siswa merupakan subjek bukan merupakan objek. Guru bertindak sebagai fasilitator dan motivator dalam proses pembelajaran. Siswa diberi kesempatan untuk mengemukakan pendapat, berefleksi, dan bebas merekonstruksi pemikiran secara individu atau melalui diskusi yang diiringi dengan keberanian bertanggung jawab. Paradigma ini mengisyaratkan bahwa guru bukan lagi menjadi satu-satunya pusat sumber belajar atau sumber pengetahuan sehingga guru harus memanfaatkan lingkungan yang ada untuk menunjang bagaimana proses pembelajaran menjadi efektif.

Tantangan ketiga adalah kualitas Sumber Daya manusia (SDM). SDM berperan penting dalam mengimprovisasi kegiatan yang telah direncanakan. Kemampuan SDM harus selalu ditingkatkan terus menerus secara berkesinambungan. Misalnya, ditemukan sejumlah guru yang telah menguasai materi pelajaran tetapi cukup banyak pula yang belum menguasai aspek-aspek yang ada dalam kurikulum. Pendeknya, ke depan dibutuhkan guru yang profesional, tidak hanya guru yang menguasai teknik, metode, strategi, dan evaluasi belajar-mengajar (to take for technician) tetapi juga memiliki sikap yang profesional (to take for aptitute). Hubungan antarpersonal, baik staf pengajar maupun non-pengajar, harus dapat diciptakan secara harmonis dan terkoordinasi, yaitu hubungan: antara guru-siswa, guru-pimpinan sekolah, guru-staf administrasi, guru-orang tua/wali siswa, dan sekolah dengan stakeholders dan lembaga pemerintah. Kerjasama ini perlu untuk mencapai tujuan secara maksimal. Namun demikian, dalam membangun hubungan ini semua harus bermuara kepada kepentingan pertumbuhan siswa.

Tantangan keempat adalah pengembangan dan pemanfaatan ipteks. Banyak siswa sampai saat ini kurang termotivasi untuk belajar. Hal ini disebabkan oleh masalah kedua di atas, belajar hanyalah kegiatan menghafal dan latihanlatihan soal. Selain itu, siswa merasa bahwa apa yang dipelajari kurang ada relevansinya dengan kehidupan nyata. Dengan menyelaraskan antara pelajaran yang dipelajari dengan dunia nyata mendorong siswa untuk belajar lebih jauh karena mereka merasa adanya manfaat dari hasil belajar mereka. Pengembangan materi pelajaran sesuai dengan kehidupan sehari tidak dapat dielakkan. Selain itu, pemanfaatan ipteks dalam kehidupan sehari harus mulai dikenalkan pada siswa. Dengan kata lain, tuntutan globalisasi adalah tuntutan Informasi dan Teknologi (IT) sehingga pengenalan IT menjadi persyaratan mutlak yang sulit dihindari agar siswa tidak gagap IT.

Tantangan kelima adalah budaya sekolah. Sekolah merupakan suatu entitas tersendiri yang memiliki kebiasaan-kebiasaan, "custom, habit, culture", yang harus dikembangkan dan disosialisasikan kepada seluruh jajaran sekolah: guru, siswa, staf dan non-staf, dan orangtua/wali siswa sebagai bagian langsung dan tak langsung dari sekolah. Kebiasaan ini mulai dari yang bersifat akademis 
maupun non-akademis. Setiap anggota sekolah sebagai bagian yang bertanggungjawab aktif harus menghormati dan mematuhi kebiasan tersebut untuk dapat mencapai tujuan bersama: menciptakan manusia berhati religius, bertindak rasional, dan berwawasan nasional dan internasional, dan lebih jauh lagi memiliki budaya mutu (quality culture) yang tercermin dalam tindakan perbaikan dan pembaharuan berkelanjutan (continous improvement) yang disebut Sallis (2005) sebagai gerakan Total Quality Management in Education. Tantangan keenam atau yang terakhir adalah kemampuan pendukung prasarana/sarana yang ada dan anggaran pendidikan dan sumber dana. Untuk mencapai tujuan yang dikehendaki perlu diperhatikan kemampuan sarana/prasarana yang ada. Suatu rencana tanpa adanya faktor pendukung tidak dapat berjalan dengan baik. Oleh sebab itu, harus ada keseimbangan antara kebutuhan dan alat pemenuhan kebutuhan. Keseimbangan ini harus dapat difahami oleh seluruh pelaku yang ada di sekolah. Tanpa pemahaman sulit dicapai suatu suasana kebersamaan dan kestabilan yang ada dan kedua hal tersebut di atas merupakan kunci keberhasilan berorganisasi.

\section{F. SEKOLAH BERKUALITAS (UNGGUL) MASA DEPAN}

Upaya peningkatan kualitas sekolah tidak lepas dari upaya untuk untuk menyelenggarakan sekolah secara efektif. Dari hasil penelitian menunjukkan bahwa suatu sekolah yang memiliki karakteristik tertentu akan dapat mencapai tujuan sekolah secara efektif. Salah satu upaya pemerintah dalam meningkatkan mutu sekolah dilakukan dengan menyosialisasikan program MBS yang dikemas dengan istilah MPMBS (Manajemen Peningkatan Mutu Berbasis Sekolah). Dalam program MPMBS dipaparkan secara jelas perencanaan-Implementasi dan Monitor-evaluasinya. Hanya saja komponen-kompenen pada MBS kurang rinci dalam memaparkan aspek-aspek yang harus dicapai. Untuk menyempurnakan program pemerintah tersebut tampaknya perlu pengayaan referensi agar MPMBS dapat diimplementasikan lebih mudah. Di antara para pakar manajemen, terdapat ahli yang memiliki resep membuat sekolah menjadi efektif atau unggul. Ahli tersebut di antaranya adalah MacBeath \& Mortimer (2001), ada sembilan hal yang harus diperhatikan untuk mengelola sekolah secara efektif yaitu: (1) visi misi jelas, 2) kepala sekolah profesional, (3) guru profesional, (4) lingkungan belajar kondusif, (5) pendidikan berbasis ramah siswa, (6) manajemen kuat, (7) kurikulum luas tetapi seimbang diiringi strategi pembelajaran yang efektif, (8) penilaian dan pelaporan prestasi siswa yang bermakna, dan (9) pelibatan masyarakat secara positif-partisipatif. Penyelenggaraan sekolah efektif atau unggul hendaknya mengacu pada sembilan hal tersebut dengan beberapa penyesuaian dalam hal perencanaan. Berikut ini diuraikan beberapa hal yang perlu dikembangkan dalam penyelenggaraan sekolah unggul. Pada setiap karakteristik tersebut di atas dijabarkan lebih lanjut yang dapat dijadikan indikator sekolah efektif atau unggul.

1. Visi dan Misi yang Jelas

2. Harapan tinggi dari siswa dan guru tercover

3. Dorongan kepada siswa untuk belajar, bekerja, berbuat, dan mengeluarkan kemampuan terbaik. 
4. Mengarahkan pengembangan intelektual, sosial, emosional, dan fisik siswa secara maksima.

5. Menekankan pentingnya pengembangan kecakapan hidup, nilai-nilai positif, dan keterampilan interpersonal.

6. Pengakuan bahwa setiap siswa adalah individu berbeda, mempunyai latar belakang, kebutuhan, dan keinginan yang berbeda.

7. Penghargaan dan sambutan yang positif atas keragaman latar belakang siswa.

8. Penekanan bahwa pendidikan adalah usaha \& tanggung-jawab bersama antara guru, siswa, dan orang tua.

9. Kepala Sekolah Profesional

a. Memiliki kualifikasi memadai, kompeten, berpengalaman.

b. Memimpin secara efektif dan menjalankan visi misi untuk membina \& memajukan masyarakat sekolah

c. Berusaha dengan sungguh-sungguh untuk meningkatkan mutu sekolah.

d. Mengelola sumber \& bahan dengan bijaksana.

e. Mampu bekerja sama dengan guru dan siswa.

f. Mampu bekerja sama dengan orang tua, komite, masyarakat dan badan terkait lainnya.

g. Meningkatkan moral staf sekolah

h. Meningkatkan belajar berkesinambungan dan melakukan pengembangan diri.

10. Guru Profesional

a. Kualifikasi memadai dan kompeten

b. Mempunyai sikap positif dan moral yang tinggi

c. Mendorong siswa untuk mencapai prestasi tinggi

d. Mengembangkan keterampilan berpikir kritis pemecahan masalah, dan kreatifitas siswa

e. Peka terhadap kebutuhan siswa

f. Menegakkan disiplin

g. Mengundang partisipasi orang tua

h. Melakukan belajar kerkesinambungan dan pengembangan profesi

i. Semua staf guru mempunyai keterampilan yang luas termasuk keterampilan dalam mata pelajaran dan dapat bekerja sama dan bekerja sebagai anggota tim yang baik

j. Lingkungan Belajar Kondusif

k. Pendidikan Berbasis Ramah Siswa

l. Manajemen yang Kuat

m. Kurikulum Luas tetapi Seimbang Diiringi Strategi Pembelajaran yang Efektif

n. Penilaian dan Pelaporan Prestasi Siswa yang Bermakna

o. Pelibatan Masyarakat secara Positif-Partisipatif

\section{DAFTAR PUSTAKA}

Abdurrahman An-Nahlawi. (1995), Pendidikan Islam di Rumah, Sekolah dan Masyarakat, Jakarta: Gema Insani Press. 
Ahmad Muflih Saefuddin. (1992), Kualitas Akademis Lulusan Tarbiyah, Makalah : Seminar Nasional dan Sarasehan Mahasiswa Tarbiyah, Prospek Tarbiyah dan Tantangannya, Pada tanggal, 22-23 Januari 1992, Senat Mahasiswa Fakultas Tarbiyah, UII, Yogyakarta.

Ahmad Azhar Basyir. (1984). Falsafah Ibadah dalam Islam, Perpustakaan Pusat UII, Yogyakarta.

Ahmad Azhar Basyir., (1985). Citra Manusia Muslim, Penerbit Fakultas Hukum UII, Yogyakarta.

Ahmad Azhar Basyir., (1988). Manusia dan Tanggung Jawab Pembinaan Kepribadian Muslim, dalam Darwin Harsono (editor), Peranan dan Tanggung Jawab, Badan Pembinaan dan Pengembangan Keagamaan Universitas Islam Indonesia, Yogyakarta.

Ali Syari'ati. (1982). Tentang Sosiologi Islam, Terj. Saifullah Mahyuddin, Yogyakarta: Ananda.

Arifin, I. (2005). Manajemen Peningkatan Mutu Sekolah Berwawasan Masa Depan. Makalah Pelatihan Guru SMA Negeri 1 Malang, 12 Nopember. Malang: SMAN 1 Malang.

Arifin, I.( 2006a). Sekolah Standar Nasional. Makalah TOT Pengembangan Profesionalisme Supervisor Madrasah, 20 September. Surabaya: IAIN Sunan Ampel Surabaya \& LAPIS Ausaid.

Arifin, I. (2006b). Kepemimpinan Komunikator Lahirkan Jawara Gugus. Seri Kisah Sukses Sekolah (Program MBS). Jakarta: Depdiknas, UNESCO, UNICEF, \& NZAID.

Arifin, I. (2007). Strategi Kepala Sekolah meraih Juara UKS Nasional: Kasus TK Anak Saleh. Yogyakarta: Aditya Media.

Bafadal, I. (2007). Pendidikan dasar: Kontribusi, artikulasi, regulasi, aktualisasi, reorientasi, dan akselerasi. Pidato pengukuhan Guru Besar Fakultas Ilmu Pendidikan. 22 Pebruari, Malang: Universitas Negeri Malang.

Bimo Walgito, Psikologi Sosial [Suatu Pengantar]. (1987). Yayasan Penerbit Fakultas Psikologi UGM, Yogyakarta.

Darmaningtyas. (1999). Pendidikan pada dan setelah krisis: evaluasi pendidikan di masa krisis. Yogyakarta: LPIST \& Pustaka Pelajar.

Departemen Agama RI, Al-Qur'an dan Terjemahannya.

Djamaludin Ancok. (1998). Membangun Kompotensi Manusia Dalam Milenium Ke Tiga, Psikologika, Jurnal Pemikiran dan Penelitian Psikologi, Fakultas Psikologi UII, Yogyakarta.

Harun Nasution. (1983). Teologi Islam, Aliran-aliran,Sejarah,Analisis Perbandingan, Jakarta: UI Press.

M. Quraish Shihab. (1996). Wawasan al-Quran, Bandung: Mizan.

M.D.Dahlan, Konsep Manusia Berkualitas Yang Dipersepsi Dari Al-Qur'an, AlHadits dan Qoul Ulama, Makalah Seminar Nasional Fakultas Syari'ah dan Fakultas Tarbiyah Universitas Islam Indonesia, Yogyakarta, tanggal, 19 Maret 1990.

Macbeath \& Mortimer. (2001). Improving school effectiveness. Buckingham: Open University Press. 
Muhammad Jamaluddin Alqasimi Addimasyqi, Mau'izhatul Mukminin min Ihya' 'Ulumuddin" Imam Alghazali", Al-Maktabah At-Tijjariyyah al-Kubro (tidak bertahun), Terjemahan Moh. Abdai Rathomy, Diponegoro, Bandung, 1973.

Musya Asy'arie. (1992). Manusia Pembentuk Kebudayaan dalam al-Qur'an, Lembaga Studi Filsafat Islam.

Rif'at Syauqi Nawawi. (1996). Konsep Manusia Menurut al-Qur'an, Makalah Disampaikan Pada Simposium Psikologi Islami, Pada Sabtu, tanggal, 14 Desember 1996, Universitas Padjadjaran, Bandung.

Rif'at Syauqi Nawawi, (2000). Konsep Manusia Menurut al-Qur'an, dalam Rendra K (Penyunting), Metodologi Psikologi Islam, Pustaka Pelajar, Yogyakarta.

Sallis, E. (2005). Total Quality Management in Education. Harlow: Longman.

Suderadjat, H. (2005). Manajemen Peningkatan Mutu Berbasis Sekolah. Bandung: Cipta Cekas Grafika.

Sukirin, (1981). Pokok-pokok Psikologi Pendidikan, Yogyakarta: FIP-IKIP.

Tilaar, H.A.R. (2002). Perubahan sosial dan pendidikan: Pedagogik transformatif untuk Indonesia. Jakarta: Grasindo.

Tilaar, H.A.R. , (2002). Pendidikan, Kebudayaan, dan Masyarakat Madani Indonesia Strategi Reformasi Pendidikan Nasional, Bandung: Remaja Rosda Karya. 